Il a été mis au point un projet de recherche interdisciplinaire sur les aspects humains du développement au Tchad. Mais la recherche fondamentale occupe toujours une place importante dans les activités des diverses sections de l'INTSH. On signalera entre autres: la définition des grands groupes linguistiques du Tchad, les études des langues Day, Mbay, Toumak (esquisse de phonologie, établissement de Lexiques . . .); la mise au point d'un projet de recherche portant sur la linguistique et la tradition orale dans le cadre du plan décennal de l'unEsco pour les langues africaines et la tradition orale.

La coopération avec les institutions similaires et les Universités nationales et étrangères se poursuit activement. Elle est caractérisée notamment par l'échange d'informations et de publications, ainsi que par l'aide matérielle apportée aux chercheurs venus de l'extérieur. Un accord vient d'être conclu avec le Centre Régional de Recherche et de Documentation pour la Tradition orale de Niamey. Il s'agit du projet sara qui s'inscrit dans le cadre du programme unesco sur les sources orales de l'Histoire de l'Afrique; ce projet intéresse également la République Centrafricaine et la République Unie du Cameroun.

Dans le domaine des publications propres à l'INTSH, il convient de signaler, au cours des années I973-74: la diffusion d'INTSH-INFORMATTONS dont deux numéros ont paru; l'édition du premier numéro de la Série $C$ des Études et Documents Tchadiens 'de la dénomination des couleurs chez les Mbay de Moïssala'; la parution, en novembre 1974, du complément bibliographique du Tchad.

\title{
Museum of Mankind: Opening of New Ethnography Store
}

THE museum possesses some 800,000 items from tribal and non-industrial societies in Africa, Asia, America, and the Pacific. This vast collection includes many famous pieces as well as comprehensive collections covering almost the whole life of some cultures. The bulk of them has now been moved to a new five-floor store which is situated at $48-56$ Orsman Road, Shoreditch, London, N. I. Access is by appointment only and applications should be sent to the Keeper of the Museum of Mankind, Mr. M. D. McLeod, at 6 Burlington Gardens, London, WIX $2 E X$. Further information can be obtained from the Keeper at the above address.

\section{Kashim Ibrahim Library}

Ahmadu Belio University Press has published an Africana catalogue of the Kashim Ibrahim Library. This provides an up-to-date source on Nigerian State Government publications, particularly those of the six Northern States, and lists present holdings for annual reports, estimates, etc. The price is $£ 2.50($ N. $4, \$ 6.50)$ and it may be obtained from the Kashim Ibrahim Library, Ahmadu Bello University, Zaria, Nigeria.

\section{'Cultures et développement' (Université Catholique de Lowvain), vol. vi, no. 3, 1974}

\section{Articles}

John P. Powezson. What went wrong in Chile? J. Sterckx. Géographie et développement. Jean-Pierre Chrétien. Des légendes africaines face à des mythes européens. B. Jewsiewicki. Administration coloniale et la tradition. A propos de Giribuma de R. Tonnoir. Romain Yakemitchouk. L'Inde, puissance nucléaire. J. van Nieuwenhove. Libération et théologie en Amérique Latine.

\section{Comptes rendus}

Ouvrages envoyés à la rédaction.

Bibliographie des Sciences du Développement. 
Tarifs d'Abonnement

4 numéros par volume, I volume par an. Belgique: FB 500. Étranger: FB. 590 . A payer par virement ou chèque bancaire à la Société Générale de Banque à Leuven (C.C.P. 9.82), pour le compte No. 230.48 I 19.27 de Cultures et Developpement. (Adresse: 62 Tervuurse Vest, 3000, LEUVEN (Belgique).)

\section{INFORMATION FOR CONTRIBUTORS}

THE Editor is pleased to receive manuscripts for publication in Africa. Contributors are asked to follow the requirements set out below. This request is not intended as an example of unnecessary and distasteful regimentation, but is to avoid waste of time, energy, and money by the publications staff of the International Institute.

Length. Manuscripts should not exceed 6,500 words (excluding bibliography). A longer manuscript may be accepted provided the author gives a subsidy of $£_{1} \mathrm{I}$ per additional thousand words.

Typing. Manuscripts should be typed double-space on quarto-size paper (English: $8 \times$ IO inches; American: $8 \frac{1}{2} \times 1 \mathrm{I}$ inches).

Footnotes and references. Footnotes should be numbered consecutively and placed together at the end of the paper. References to publications should be placed in the text, in parentheses, and a bibliography provided at the end of the article. References in the text should be in the form (Forde, 1964: 102). References in the bibliography should be in the form:

for books: Forde, D. 1964. Yakö Studies. London, Oxford University Press.

for articles: Forde, D. 1950. 'Ward Organization among the Yakö', Africa, xx (4), 267-89.

Special characters. These should be avoided, wherever possible

Tables, maps, diagrams, and figures. These should be placed separately at the end of the article, each on a separate sheet of paper and numbered. The number should also be placed in the text where the author wishes it to go.

Photographs. These should be numbered, with accompanying captions. Authors are usually asked for a subsidy for photographs.

Abstracts. Each article should have an abstract, of not more than 400 words, for translation into French or English as the case may be. Details about the author, for the section 'Notes on Contributors', should also be included.

Proofs. The printers now provide only page proofs, so that additional material cannot be added at this stage. Authors are sent proofs, to be returned as quickly as possible to the Editor.

Offprints. An author receives 25 free offprints; he may order more, on payment, when submitting an article. The editor reserves the right to make editorial revisions, but he will not make major changes without the author's approval. 